\title{
DESIGN AND MANUFACTURING OF A PROTOTYPE FOR SUNFLOWER SEEDS HULLING
}

\author{
Gamea, G. R* and Mohmed, M. E.**
}

\section{ABSTRACT}

Sunflower seed oil is considered to be one of the major edible oil in the world. In Egypt sunflower became an important crop as a source of oil and protein. Attention was paid for extending the cultivated area and growing varieties of high oil content to cover a part of the deficit in the production of edible oils. Sunflower is considered multipurpose crop, but oil was largest usage. If the seed hulls are removed before processing it leads to decrease the production cost of edible oil and decrease the wax and coloring matters. So that, sunflower seeds need to be hulled and a hulling machine is needed to reduce the wax and coloring matters. The main objective of present study is to investigate the effect of some factors affecting performance of prototype for sunflower seeds hulling. In order to fulfill the aim of study, the hulling prototype was manufactured with tools to control rotating disc speed, clearance between rotating disc and fixed disc. The result showed that the best degrees of hulling efficiency obtained with the best broken kernel percentage were at 1500 r.p.m rotating disc speed, $3 \mathrm{~mm}$ clearance, 40 $\mathrm{cm}$ rotating disc diameter. The highest obtained values of hulling efficiency were $(70.21 \%)$ with $(9.1 \%)$ broken kernel at $10 \%$ moisture content, (77.52\%) with (20.1\%) broken kernel at 8\% moisture content and $(83.99 \%)$ with $(22.3 \%)$ broken kernel at $6 \%$ moisture content. The prototypes succeeded as a step forward to the complete design.

\section{INTRODUCTION}

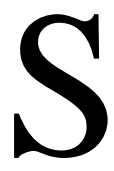
unflower seeds are a great source of dietary fiber, protein, and complex carbohydrates. This makes them a great food source for active people who need a steady supply of protein and complex carbohydrates for energy, weight loss, and muscle gain. Just a handful of sunflower seeds will provide $90 \%$ of your daily value of vitamin E. Vitamin E travels

\footnotetext{
* Associate prof. of Agric. Eng., Fac. of Agric., Minoufiya Univ.

**Associate lecturer of Agric. Eng., Fac. of Agric., Minoufiya Univ.
} 
through the body killing free radicals and protecting the body's cellular and molecular components while also providing nourishment. Vitamin E has significant anti-inflammatory effects, reducing the harsh symptoms of asthma and arthritis.

It has also been shown to reduce the risk of colon cancer, the intensity of hot flashes, and diabetes. Sunflower seeds are a great source of magnesium, helping to strengthen bones, lower high blood pressure, prevent migraine headaches, and reduce the risk of heart attacks and strokes. Sunflower seeds also improve brain function. This is due to their high levels of tryptophan. When foods that contain tryptophan are consumed, the brain's production of serotonin is increased. High levels of serotonin give the brain a relaxing and focusing effect. By eating sunflower seeds on a regular basis, you will benefit from nutrients, minerals, and fiber that will improve your overall bodily health. Sunflower seeds crop are one of the world's leading oilseed crops, it followed the soybean crop for total oil production (Ibrahim and Sharaan, 1991). The oil production in Egypt has a great problem due to the high gap between production and consumption. The production of both cotton and soybean crops, which considered the main source of oil, affect oil production. Therefore, the direction toward untraditional oil crops such as sunflower seeds becomes more intended. Sunflower could be planted under different climate condition; all soil types and need a short growing period (Morsy, 1980). Sunflower seed has a dry brittle hull enclosing a whitish kernel with a thin translucent skin coat. Sunflower seed (Vidoc variety) contains $37.5 \%$ oil. The high fiber, low protein, low oil (1\%), high wax and coloring matter content of the hull are major constraints in getting a better yield of oil and good quality of protein. An integrated cost effective process is now available to obtain superior quality oil as well as meal. The meal from the sunflower seed after hulling can be used for preparation of Tosta bread, Tahina and confectionery items. The oil is of edible quality, rich in unsaturated fatty acids (Mostafa, 2001). Sunflower seeds deem to replace sesame in the production of "halawa tahineia " and " tehina ". (tehina is a fatty dresser usually made from sesame seeds. Halawa tehineia is an Egyption name for a sweet taste manufactured from tahina and sugar). From the 
economical, technological and nutritional point of view in food industry (Radwan, 1987), the use of sunflower seeds tahina as fresh tahina or in suitable sunflower halawa manufacture is more reasonable. Hulling is a process of removing hulls from the oil bearing seeds for obtaining high quality edible oil by the processing of kernels. This reduces fibrous content of the meal and increases the marketability as stock feed. About $99 \%$ of oil is stored naturally in kernels and the hulls contain not more than $1 \%$ oil. If the hulls are not removed they reduce the total yield of oil by absorbing or retaining oil in the pressed cake. In addition to this the wax and coloring matters present in the hulls get mixed with the expressed edible oil. This necessitated the refining process, and therefore, increases the production cost of edible oil. Moreover, processing oilseeds without dehulling reduces the capacity of the extraction equipment in addition to more repair and maintenance costs. A large proportion of oil is retained by the high percentage of hull of oilseeds. If the hulls are removed from the seed before processing, it would yield comparatively more volume of oil (Canada, 1998).

Sunflower seeds need to be hulled; therefore a hulling machine is needed. The sunflower huller used either for direct seeds consume or for hulling before oil pressing. Therefore, the aim of this research can be achieved after carrying out three procedures, first includes the study of some physical characteristics for sunflower seeds and kernels. The second is, to carry out a series of experiments to specify the optimum conditions of hulling operation, which ensure the highest grade of hulling efficiency with minimum percent of broken kernels. The main objective of present study is to investigate the effect of some factors affecting performance of prototype for sunflower seeds hulling.

\section{MATERIALS AND METHODS}

The present study was carried out under hulling prototype which was designed and manufactured at the Agricultural Engineering workshop, Faculty of Agriculture, El-Minoufiya University. Advantages of this prototype are simplicity, low cost manufacture, all parts from local materials and ease of construction. 


\section{Materials}

Sample of the sunflower seeds (Vidoc variety) were taken from Oil Crops Institute, Ministry of Agriculture. The sunflower seeds were cleaned manually from foreign matter and broken and immature seeds and stored in tightly sealed bin.

\section{Experimental prototype}

The hulling unit as schematically depicted in figure (1) consists of the following parts:

The hulling chamber contains a pair of rotating and fixed discs. The rotating disc was made from mild steel with a thickness of $5 \mathrm{~mm}$. Two different diameters of the rotating disc were used the first one was $400 \mathrm{~mm}$ and the second was $350 \mathrm{~mm}$. The rotating disc rotate over the fixed disc. The diameter of the fixed disc was $450 \mathrm{~mm}$. The fixed disc and rotating disc coated by rough rubber with $8 \mathrm{~mm}$ thickness. The rubber qualities are $60 \pm 5$ hardness (share), $30 \mathrm{M} \mathrm{Pa} / 2 \mathrm{Ply}$ tensile strength and $300 \%$ elongation. The clearance between the fixed disc and the rotating disc was adjusted to be 2,3 and $4 \mathrm{~mm}$. The rotating disc was connected with vertical sliding tube of $30 \mathrm{~mm}$ diameter, which rotate at different speeds by transmission pulleys and belt by an electric motor of $750 \mathrm{~W}$. The study was conducted under three levels of rotational speed of the rotating disc which are 1000, 1500 and 2000 r.p.m. An electrical motor of $750 \mathrm{~W}$ with 1440 r.p.m was used to drive the experimental prototype. The hopper was fixed on the top of hulling chamber to easily feed the sunflower seed. It was manufactured from galvanized smooth steel sheet. Discharge gate is located at the hulling chamber base. A bag was fixed on it to receive the discharged product (hulls and seeds). The frame was constructed from a hollow and channel steel section.

\section{Tested factors for hulling prototype}

The main tested factors for hulling unit were moisture content of seeds, clearance between discs, rotating speed and disc diameter to evaluate the hulling efficiency, broken kernel percentage and power requirement. The variables levels were as the following: 
1- Three levels of moisture content $(6,8$ and $10 \%)$.

2- Three values of clearances (2, 3 and $4 \mathrm{~mm}$ ) between hulling rotating and fixed discs.

3 - Three speeds of the rotating disc (1000, 1500 and 2000 r.p.m).

4- Two different diameters of the rotating disc (350 and $400 \mathrm{~mm})$.

\section{Measurements}

The following measuring instruments were used in the present study:

1. Determination of grain dimensions

The shape and size of seeds were derived by measuring length (L), width $(\mathrm{W})$, thickness $(\mathrm{T})$, geometric diameter $(\mathrm{Gd})$ and arithmetic diameter (Ad). The mean dimensions (L, W, and $\mathrm{T}$ ) for each seed were estimated by vernier calipers. The following equations (El-Raie, 1987) were used to calculate the values of the physical characteristics for sunflower seeds:

$$
\begin{aligned}
& V=\pi / 6(L W T), m^{3} . \\
& G d=(L W T)^{1 / 3}, m m \\
& A d=(L+W+T) / 3, \mathrm{~mm} \\
& S \%=100(L W T)^{1 / 3} / L, \% \\
& F s=\pi / 4 L W, \mathrm{~mm}^{2} \text {. } \\
& T s=\pi / 4 T W, m^{2}
\end{aligned}
$$

2. Determination of friction angle

The friction angle for samples (seeds, kernel and hull) was measured against two structural materials, rough rubber and galvanized iron. The board on which the sunflower material was carried, was tilted slowly and gradually until the seeds overcomes the static friction and begin to slide downwards over the plane. At this moment, the declination angle of the board is recorded. 


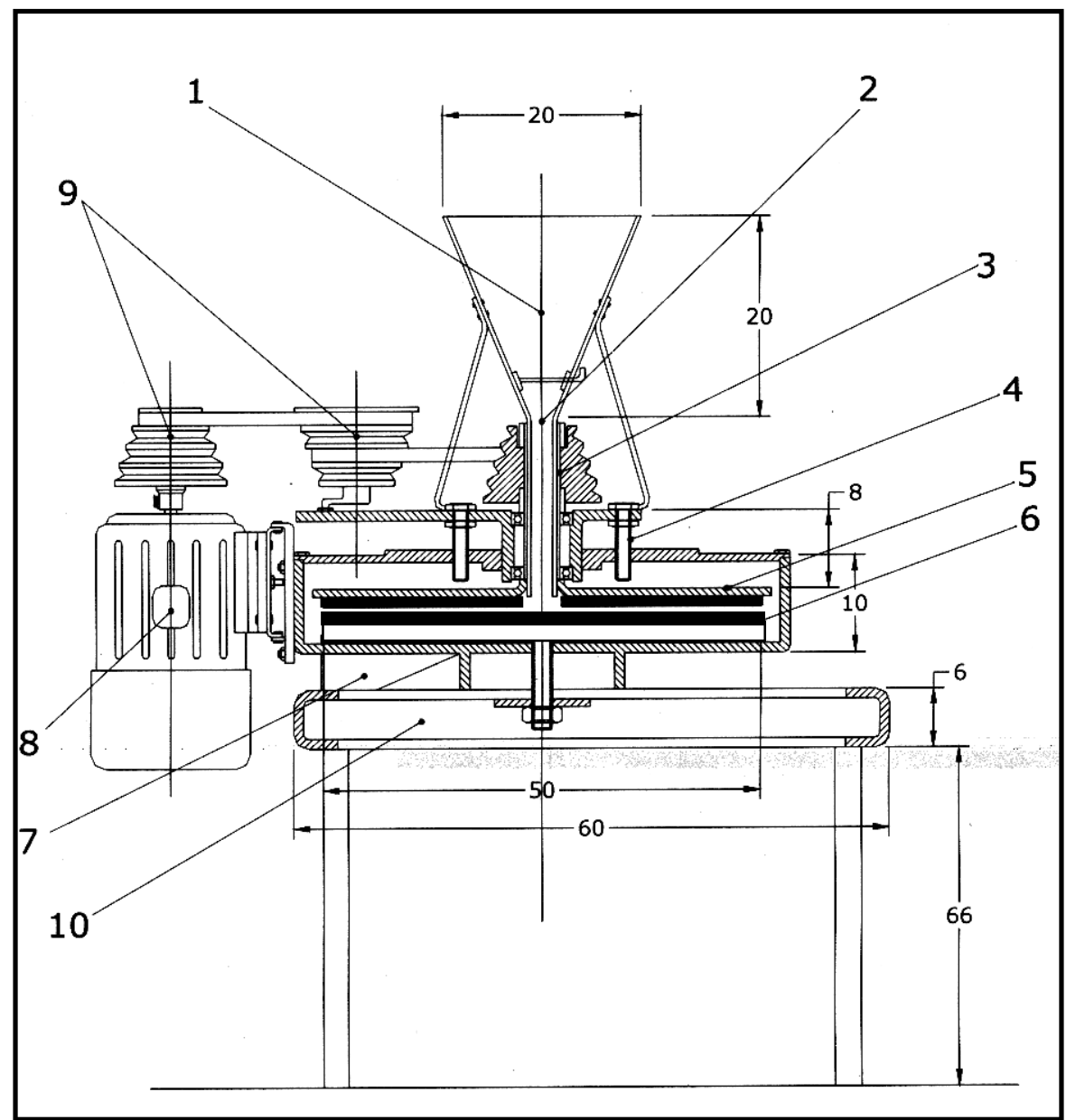

1- Hopper;

6- Rough rubber;

2- Feeding tube;

7- Discharge gate;

3- Sliding tube;

8- Electric motor;

4- Clearance gauge;

5- Rotating disc;

9- Belts and pulleys transmission device; 10-Fram.

DIMS in $\mathrm{cm}$

Fig. (1): Cross sectional elevation for the hulling unit.

3. Determination of repose angle

Angle of natural slop (repose angle) is the angle at which the seed does not move when forming a cone. The designed combined parallelogram and protractor was used to measure the angle between the horizontal base and the inclined side of the formed cone due to the free vertical fall of the seeds. Each experiment was 
repeated 10 times to calculate the value of angle of repose for each sample.

4. Determination of moisture content

The moisture content of the seeds was determined using an electric oven adjusted at $\left(105^{\circ} \mathrm{c}\right)$ for 24 hours. The moisture content percentage was calculated on dry bases according to the following equation:

$$
\text { M.c }=\frac{M w-M d}{M d} \times 100 \quad, \%
$$

Where:

M.c = sample moisture content on dry basis, \%;

$M w=$ Weight of wet sample;

$M d=$ Weight of dry sample.

5. Determination of real and bulk densities

\section{1-Particle density}

Particle density was calculated for a random sample of hundred seeds and kernels of sunflower as follows:

$$
D_{r}=M / V_{1} \quad, \mathrm{~g} / \mathrm{cm}^{3}
$$

Where:

$D_{r}=$ Particle density of the individual seeds or kernels, $\mathrm{g} / \mathrm{cm}^{3}$;

$M=$ Mass of the individual seeds or kernels, $g$;

$V_{l}=$ Volume of the individual seeds or kernels, $\mathrm{cm}^{3}$.

Volume of the individual seeds was measured by means of increasing the volume of $5 \mathrm{~mL}$ of sodium nitrate solution subjected in a small graduate cylinder when the particle was put in the solution.

2-Bulk density

Bulk density was calculated for the seeds and kernel of sunflower, by dividing the mass of quantity of a specific seeds and kernels on its volume, which was measured by using graduate cylinder as follows:

$D_{b}=M / V \quad, \mathrm{~g} / \mathrm{cm}^{3}$

Where: 
$D_{b}=$ bulk density of the seeds or kernels, $\mathrm{g} / \mathrm{cm}^{3}$;

$M=$ mass of seeds or kernels, $g$;

$V=$ Volume of the seeds or kernels, $\mathrm{cm}^{3}$.

\section{Electric power}

A clamp meter and Voltmeter were used for measuring current intensity and voltage respectively. In order to increase the sensitivity of the electric current intensity reading due to the different treatments, two coil rings in series were prepared using enameled wire of 10 and 50 turns respectively with inner diameter of $70 \mathrm{~mm}$.The wire was connected with an electric plug at one end and electric socket at the other end. The coil wire was plugged to the electric source and turns were inserted inside the transformer jaws of the clamp meter, the actual reading was magnified 10 times. Also, at coil ring with 50 turns the actual reading was magnified 50 times.

The electric power (P, Watt) was calculated based on current intensity (I, Ampere) and the voltage (V, volt) measurements, using the following formula:

$$
P=\operatorname{Cos} \theta \text {. I. V. }
$$

Where:

$$
\operatorname{Cos} \theta=\text { Power factor (being equal to 0.85) }
$$

7. Hulling performance

The performance of hulling unit was calculated from the point of view of percentage of broken kernels, hulling efficiency and net consumptive energy.

1. Percentage of broken kernels

The Percentage of broken kernel $(\mathrm{B} \%)$ was calculated by the following formula (Ismail, 1994) and (Abel - Mageed, 1989):

$$
B \%=M_{1} / M \times 100
$$

Where:

$$
\begin{aligned}
& B=\text { Percentage of broken kernel } \% ; \\
& M_{1}=\text { Mass of broken kernel, } g ; \\
& M=\text { Total mass of the sample, } g .
\end{aligned}
$$

2. Hulling efficiency 
The hulling efficiency (E) for the modified huller was calculated by the following formula (Tayel and khairy, 1988) as a complementary expression of the hulling performance of sunflower huller:

$$
H=\left(1-M_{2} / M\right) \times 100 \%
$$

Where:

$$
\begin{aligned}
& H=\text { Hulling efficiency, } \% \\
& M_{2}=\text { Mass of unshelled seeds, } g \\
& M=\text { Total sample mass, } g .
\end{aligned}
$$

3. Net consumptive energy

Net consumptive energy was calculated by the following formula:

Net power $=$ Electric power $($ load) - Electric power $($ no load)

Net consumptive energy was calculated by the following formula:

$$
E=P / R
$$

Where:

\section{The statistical analysis}

$$
\begin{aligned}
& E=\text { Net power consumptive, } W . h / \mathrm{kg} ; \\
& P=\text { Net power }, W \\
& R=\text { Feeding rate, } \mathrm{kg} / \mathrm{h} .
\end{aligned}
$$

The experiments were arranged in a randomized complete block design using factorial analysis of variance with three replicates. The analysis of variance was executed by SPSS program.

\section{RESULTS AND DISCUSSIONS}

The obtained results were analyzed and divided into two main headings which are:

1- Physical characteristics of sunflower seeds.

2- Performance of hulling prototype in hulling sunflower seeds.

\section{Physical characteristics of sunflower seeds}

The most important physical characteristics of sunflower seeds for (Vidoc variety) which considered in design of the hulling prototype as follows:

Length (10-13.6 mm), width (4.5-7 mm), thickness $(2.5-4.8 \mathrm{~mm})$, rigidity force $(20-33 \mathrm{~N})$ longitudinal, $(15-32 \mathrm{~N})$ lateral and $(10-18 \mathrm{~N})$ transverse, repose angle $\left(29^{\circ}-34^{\circ}\right)$ and coefficient friction angle $\left(22^{\circ}\right.$ - 
$\left.24^{\circ}\right),\left(48^{\circ}-58^{\circ}\right)$ for seeds with galvanized iron and with rubber respectively.

\section{Performance of hulling prototype in hulling sunflower seeds}

Determination of the performance of hulling unit was established in terms of three main parameters which are hulling efficiency, percentage of broken kernels and net consumptive energy for hulling operation of sunflower seeds.

\section{Hulling efficiency}

The variation of the tested factors (speed of the rotating disc, clearance, moisture content of seeds and diameter of the rotating disc) affected on the value of hulling efficiency. Figure (2) shows the relationship between the rotating disc speed and hulling efficiency at different values of clearance (2, 3 and $4 \mathrm{~mm})$. The results showed that, hulling efficiency increased with increasing rotating disc speed and decreasing the clearance distance. This increasing may due to increasing the rate of seeds knocked by the friction surfaces. This result is in agreement with Tayel and Khairy, (1988). The obtained minimum hulling efficiency was $25.35 \%$ obtained at the rotating disc speed of $1000 \mathrm{rpm}$ and clearance of 4 $\mathrm{mm}$. While, the obtained highest hulling efficiency was $86.58 \%$ at the rotating disc speed of $2000 \mathrm{rpm}$ and clearance of $2 \mathrm{~mm}$. It is clear that, for all rotating disc speeds the highest clearance $4 \mathrm{~mm}$ caused a big reduction in hulling efficiency. Figure (3) shows the effect of rotating disc speed on hulling efficiency at different values of disc diameter. It showed that, increase the rotating disc speed and disc diameter increases the hulling efficiency. The highest hulling efficiency was $82.09 \%$ at $2000 \mathrm{rpm}$ rotating disc speed and $400 \mathrm{~mm}$ disc diameter. While the lowest hulling efficiency was $48.22 \%$ at $1000 \mathrm{rpm}$ rotating disc speed and $350 \mathrm{~mm}$ disc diameter. The effect of rotating disc speed on hulling efficiency at different values of moisture content was presented in figure (4). The results indicated that, increasing the rotating disc speed increased the hulling efficiency at all levels of moisture contents. But increasing the values of moisture content decreased the hulling efficiency. The highest value of hulling efficiency $(84.26 \%)$ was at $2000 \mathrm{rpm}$ 
rotating disc speed and $6 \%$ moisture content. However, the lowest value of hulling efficiency $(42.34 \%)$ was at $1000 \mathrm{rpm}$ rotating disc speed and $10 \%$ moisture content.

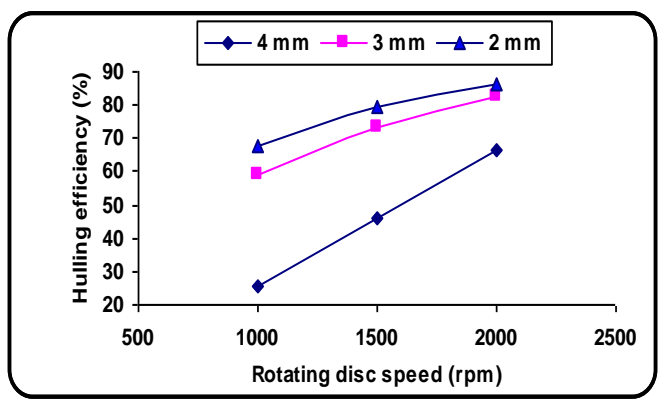

Fig. (2): Effect of disc speed on the mean hulling efficiency at different clearance.

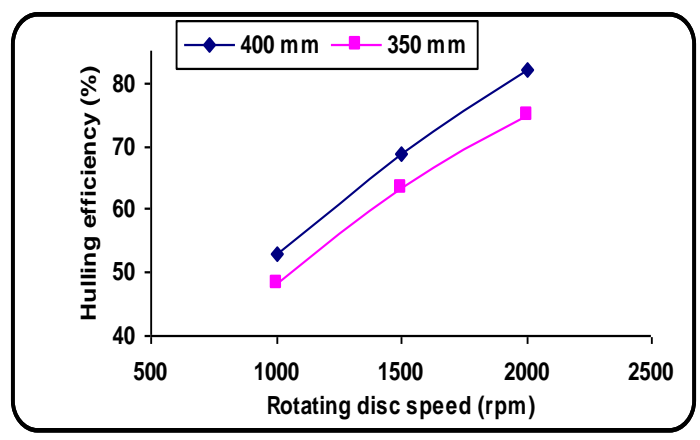

Fig. (3): Effect of disc speed on the mean value of the hulling efficiency at different disc diameters.

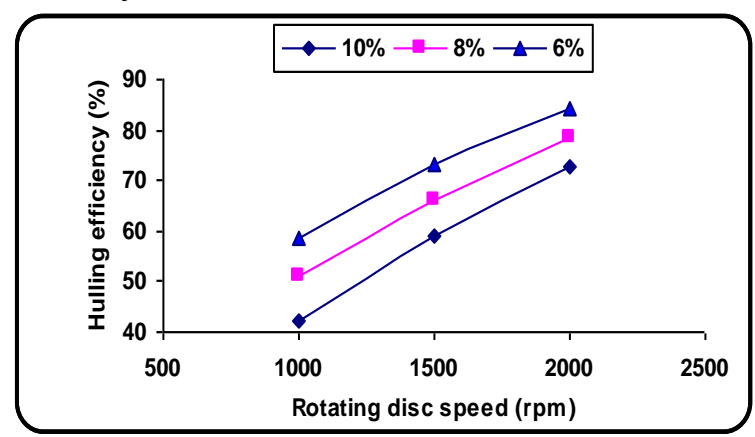

Fig. (4): Effect of disc speed on the mean hulling efficiency at different moisture contents. 

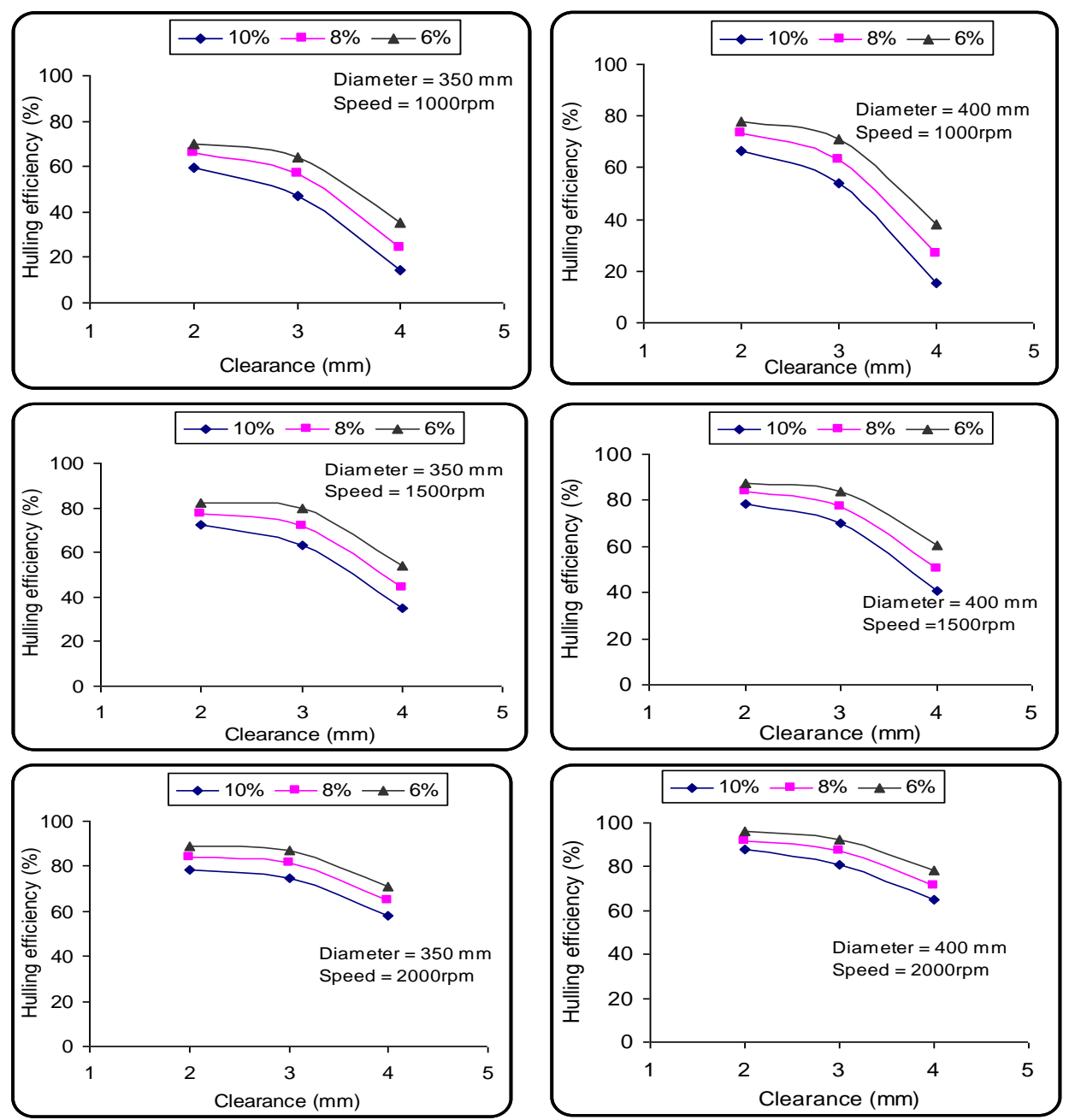

Fig. (5): Effect of clearance on the value of hulling efficiency at different levels of moisture content, rotating speed and disc diameter.

Figure (5) show the hulling efficiency as affected by clearance and moisture content at three values of rotating disc speed. At all moisture content levels, it was observed that, increasing clearance from $3 \mathrm{~mm}$ to $4 \mathrm{~mm}$, the decreasing rate for hulling efficiency is more than the decreasing rate of clearance from 2 to $3 \mathrm{~mm}$. This is may be due to that, any increment in the than $3 \mathrm{~mm}$, led to be the clearance more than the thickness of most of the sunflower seeds. The hulling efficiency seemed to be affected by clearance with the increase of rotating disc speed from 1000 to $2000 \mathrm{rpm}$ at all levels of moisture contents. It means that the 
decrease of the clearance and moisture content increase of hulling efficiency, but it leads to an increase of broken kernel. The highest hulling efficiency (96.29\%) was at the interaction of $2 \mathrm{~mm}$ clearance, $400 \mathrm{~mm}$ disc diameter, $2000 \mathrm{rpm}$ rotating disc diameter and $6 \%$ moisture content. While, the lowest hulling efficiency (14.34\%) was at $4 \mathrm{~mm}$ clearance, $350 \mathrm{~mm}$ disc diameter $1000 \mathrm{rpm}$ rotating disc speed and $10 \%$ moisture content.

\section{Percentage of broken kernels}

The value of the percentage of broken kernels was affected due to the variation of the tested factors (speed of the rotating disc, clearance, moisture content of seeds and diameter of the rotating disc). Each factor discussed individually as follows:

Figure (6) shows the relationship between the rotating disc speed and the mean value of broken kernel percentage at different values of clearance (2, 3 and $4 \mathrm{~mm})$. The results show that, the broken kernel percentage increased with the increasing the rotating disc speed. The minimum percentage was $2.59 \%$ obtained when the rotating disc speed and clearance were $1000 \mathrm{rpm}$ and $4 \mathrm{~mm}$ respectively. While, the maximum value was $22.09 \%$ at the rotating, disc speed and clearance of $2000 \mathrm{rpm}$ and $2 \mathrm{~mm}$ respectively. The effect of rotating disc speed on broken kernel percentage at different values of moisture content of seeds was presented in figure (7). It showed that, increasing the rotating disc speed increased the percentage of broken kernel percentage at all levels of moisture contents. But increasing the values of moisture content decreased the broken kernel percentage. Figure (8) shows the relationship between the mean value of the broken kernel percentage and clearance at the different levels of moisture content. The obtained results indicated that, increasing the clearance decreased the broken kernel percentage. The highest value of broken kernel percentage $(23.27 \%)$ was observed at $2 \mathrm{~mm}$ clearance and 6\% moisture content. However, the lowest value $(4.37 \%)$ was found at $4 \mathrm{~mm}$ clearance and $10 \%$ sample moisture content. 


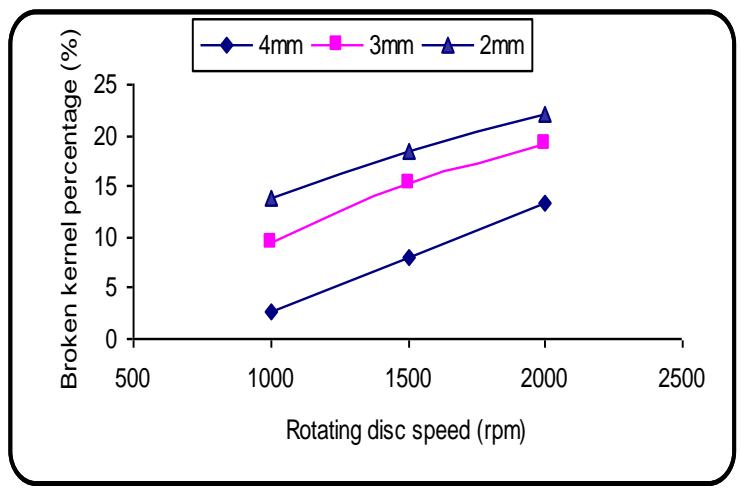

Fig. (6): Effect of rotating disc speed on the mean value of the broken kernel percentage at different values of clearance.

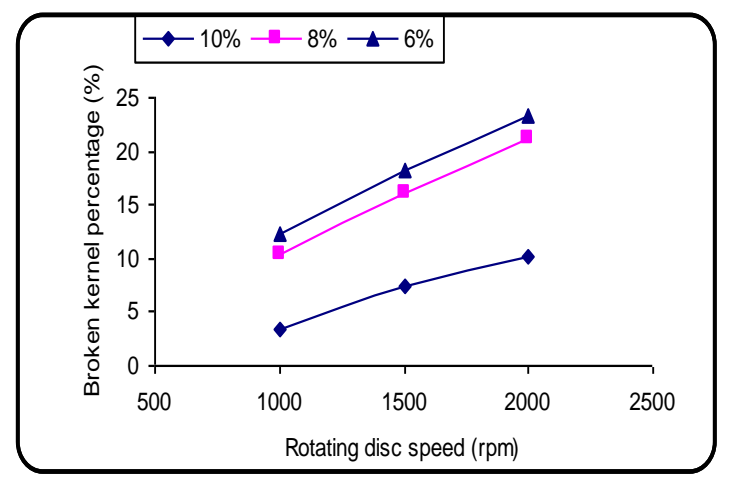

Fig. (7): Effect of rotating disc speed on the mean value of the broken kernel percentage at different values of moisture content.

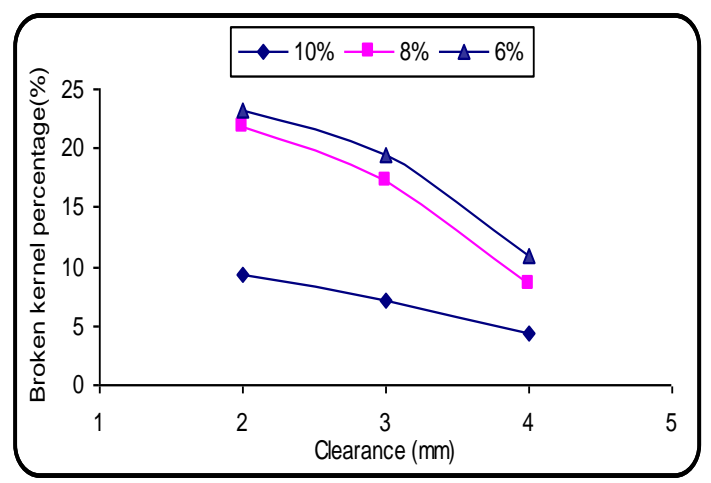

Fig. (8): Effect of clearance on the mean value of broken kernel Percentage at different values of moisture content. 


\section{Net consumptive energy for hulling operation of sunflower seeds}

Figure (9) illustrated the power consumed as affected by the interaction between clearance and rotating disc speed at different moisture content and different values of rotating disc diameter. From this figure we can observed that, the power consumed seemed to be affected by clearance with the increase of rotating disc speed from 1000 to $2000 \mathrm{rpm}$ at all levels of moisture content.
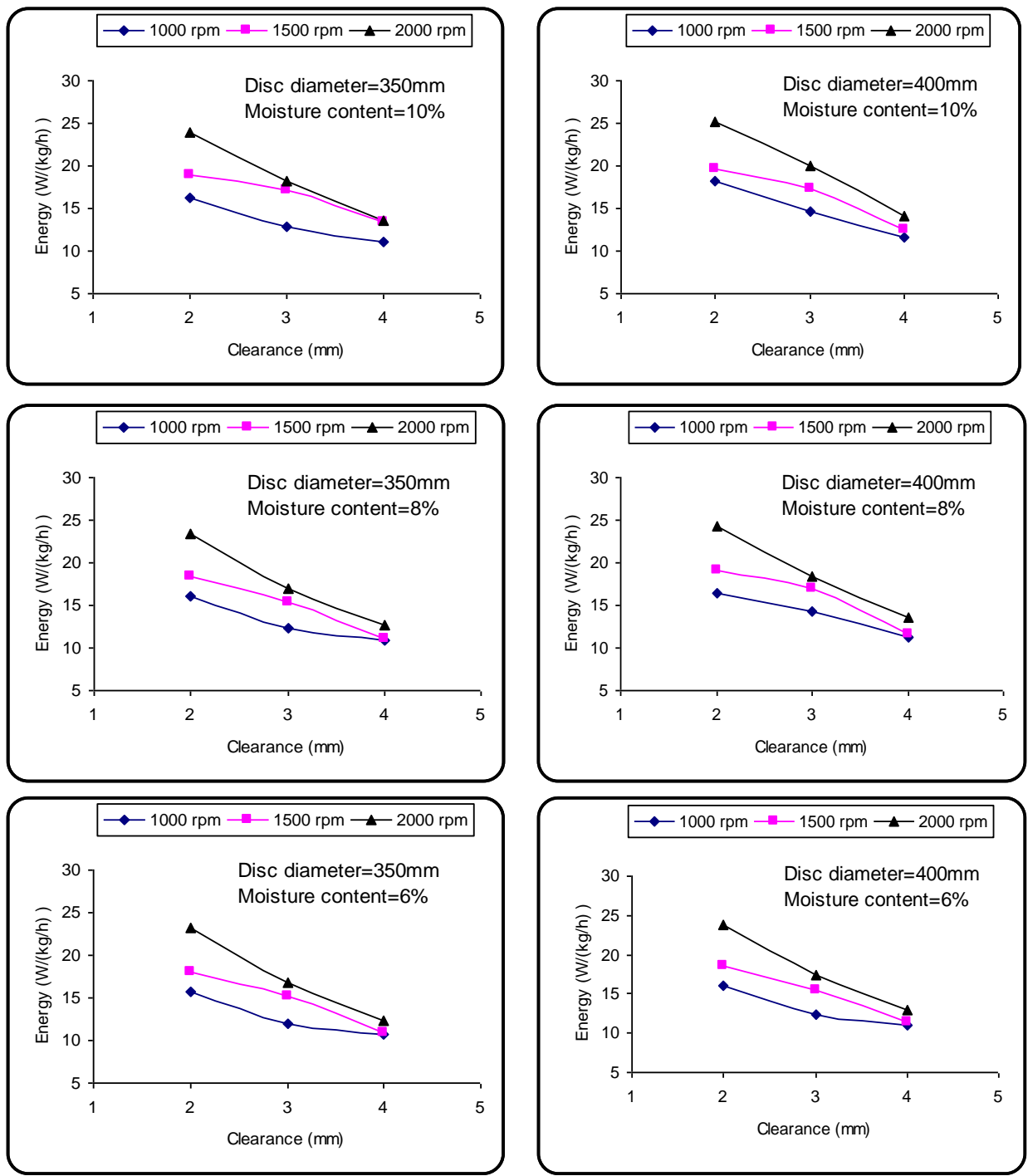

Fig. (9): Effect of clearance on the power consumed at different levels of rotating speed, moisture contents and disc diameters. 
The power consumed decreased when the clearance increases from 2 to 4 $\mathrm{mm}$ for all rotating disc speed. Also, the results indicated that, increasing the rotating disc speed, moisture content and rotating disc diameter increased the power consumed. At all moisture content and rotating disc diameters, it was observed that, increasing of the rotating disc speed from 1000 to $2000 \mathrm{rpm}$, led to increase the rate of power consumed at $2 \mathrm{~mm}$ clearance more than the increasing rate at $4 \mathrm{~mm}$ clearance. The interactions of clearance, moisture content and rotating disc speed were found to be highly significant. The highest value of power consumed was $(25.09 \mathrm{~W} /(\mathrm{kg} / \mathrm{h}))$ obtained at the interaction of $2 \mathrm{~mm}$ clearance, $2000 \mathrm{rpm}$ rotating disc speed, $10 \%$ moisture content, and $400 \mathrm{~mm}$ disc diameter. While, the lowest value of power consumed was $(10.71 \mathrm{~W} /(\mathrm{kg} / \mathrm{h}))$ at the interaction of $4 \mathrm{~mm}$ clearance, $1000 \mathrm{rpm}$ rotating disc speed, 6\% moisture content, and $350 \mathrm{~mm}$ disc diameter.

\section{CONCLUSION}

1- The rotating disc speed has effect on the hulling efficiency. However, it affects the broken kernel percentage and net energy consumption at all the different moisture content. Increasing rotating disc speed led to increases the hulling efficiency broken kernel percentage and net energy consumption.

2- At all moisture content levels, at increasing clearance from $3 \mathrm{~mm}$ to $4 \mathrm{~mm}$, the decreasing rate for hulling efficiency is more than the decreasing rate at increasing clearance from 2 to $3 \mathrm{~mm}$. also, increasing the clearance decreasing the broken kernel percentage.

3- The hulling efficiency and net energy consumption increased by increasing of rotating disc diameter. Also the broken kernel percentage increased.

4- Increasing the moisture content from 6 to $10 \%$ decreased the hulling efficiency and increased the net energy consumption. Increasing the moisture content from 6 to 8 did not affect the broken kernel percentage but at increasing from 8 to $10 \%$ decreased the broken kernel percentage, especially at $400 \mathrm{~mm}$ disc diameter and all levels of different factors. 
The best degrees of hulling efficiency obtained with the best degrees of broken kernel percentage were at 1500r.p.m rotating disc speed, $3 \mathrm{~mm}$ clearance, $40 \mathrm{~cm}$ rotating disc diameter.The increasing of broken kernel percentage will not make a serious problem because the broken kernels will not affect the production of oil and tehina or other products, but the problem will appears in the separating operations depending on terminal velocity. The prototype succeeded for purpose as a step forward to the complete design.

\section{REFERENCES}

Abdel-Mageed. H. N. (1989), Lentil hulling as affected by grain treatments and husking machine performance. Misr j. Ag. Eng., 6(2): 166- 176.

El-Raie, A. E. S. (1987), Properties of shelled corn related to mechanical separation. Misr J. Ag. Eng., 4(1), P: 36-51.

Ismail. Z. E. (1994), Development of a local rice husker machine for lentil hulling. Misr j. Ag. Eng., 11(1): 210-226.

International Development Research Center, Ottawa, Canada. Chapter (3) Hulling and processing of oil seeds. Updated: 10 november (1998).

Radwan, S. M. (1987), Engineering studies on determining rice processing losses. Unpublished M. SC. Thesis, Dept. of Ag. Mech. Mansoura uni., PP. 120.

Tayel, S. A. and M. F. A.. Khairy. (1988), Astudy on some design criteria of sunflower shelling machine. Misr j. AG. Eng., 5 (3): 307- 316.

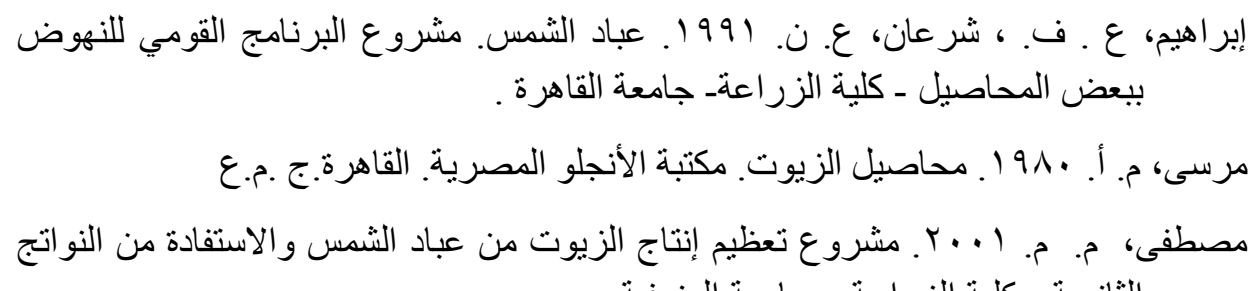
الثانوية ـ كلية الزر اعة - جامعة المنوفية. 
PROCESS ENGINEERING

\section{الملخص العربي}

\section{تصميم وتصنيع نموذج مبئي لتقشير بذور عباد الثمس}

\section{د/ جمال رشاد جامع" م.م/ ماجد السبد أحمد محمد**}

يعتبر زيت عباد الثمس أحد الزيوت الرئيسية المنتجة بالعالم. ولقد أصبح عباد الثمس في مصر

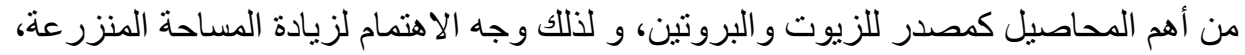

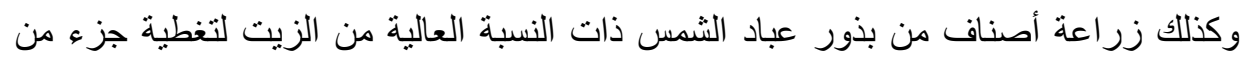
النقص في إنتاج الزيوت الغذائية. ولقد وجد أنه في حالة تقثير البذور قبل عملية استخراج

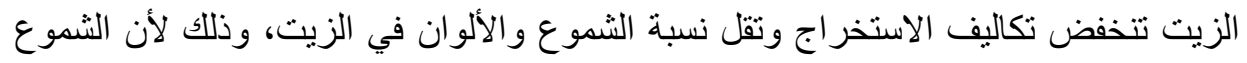

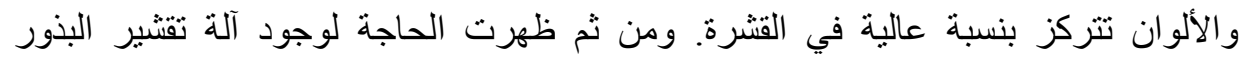

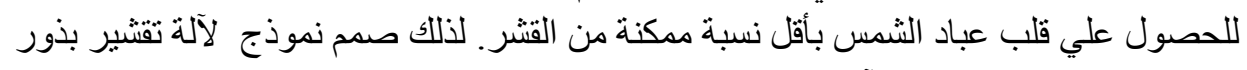
عباد الشمس وكذلك نموذج لآلة تفصل القلب عن القشر. ولقد تم دراسة بعض الخو اص الطبيعية

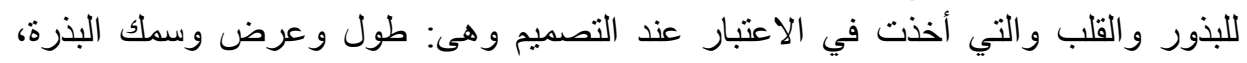

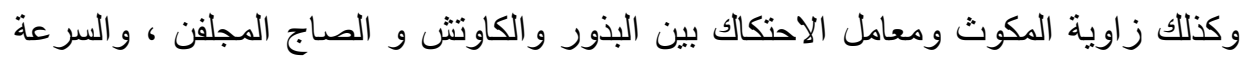
الحرجة للبذور و القلب والقشر، وقوة الصلابة ـ ويعتبر الهدف الرئيسي من هذه الدراسة هو دراسة تأثير بعض العوامل المؤثرة على أداء نموذج تقثير بذوة الثور عباد الثمس. وكانت

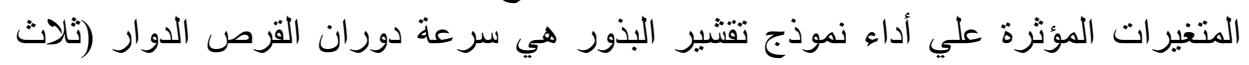

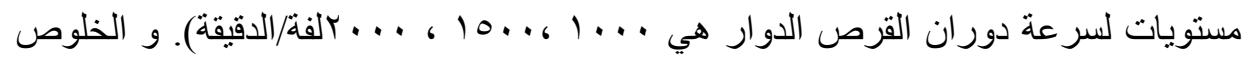

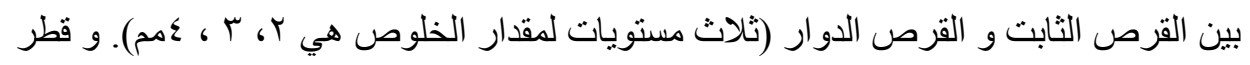

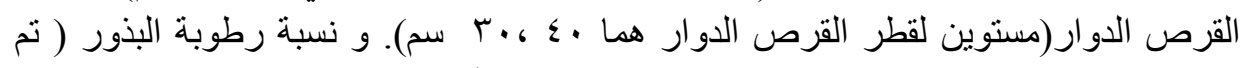

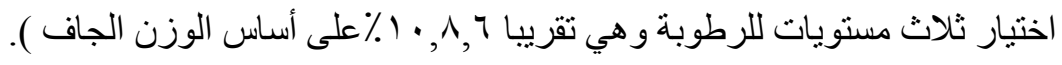
وتتلخص نتائج الدر اسة فيما يلي:

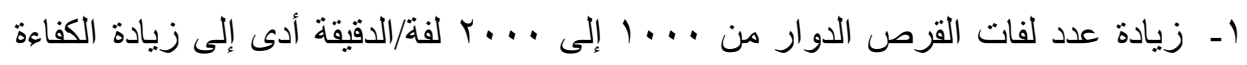

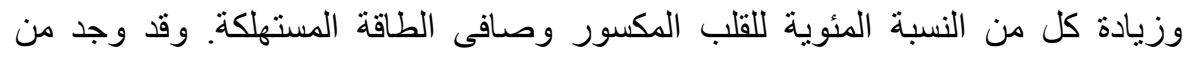
التجارب أن أنسب سر عة للدوران هي ل . ـ 1 لفة/الدقيقة. ץ- زيادة الخلوص أدى إلى انخفاض كفاءة التقنير بنسبة كبيرة وكذلك النسبة المئوية للقلب المكسور وصافى الطاقة المستهلكة.

بـ زادت كفاءة التقشير بزيادة قطر القرص الدوار وكذلك النسبة المئوية للقلب المكسور وصافى الطاقة المستهلكة.

* أستاذ مساعد بقسم الهندسة الزراعية ـ كلية الزراعة ـ جامعة المنوفية

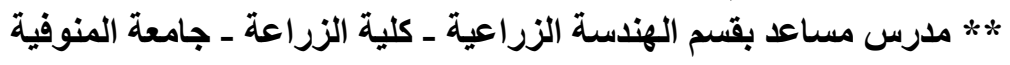




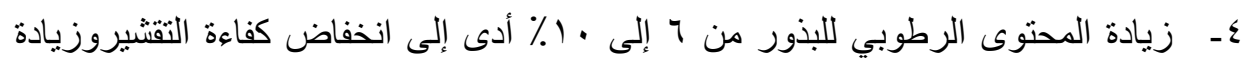

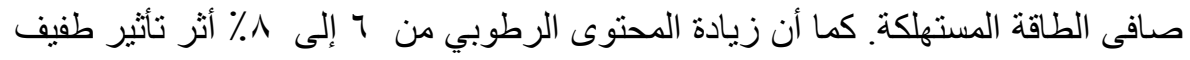

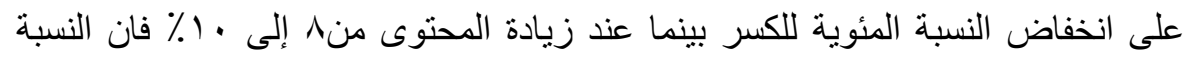

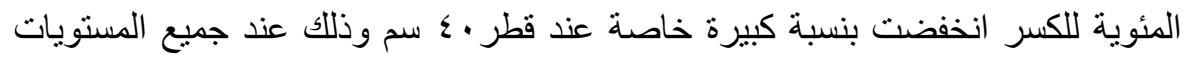

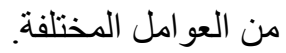

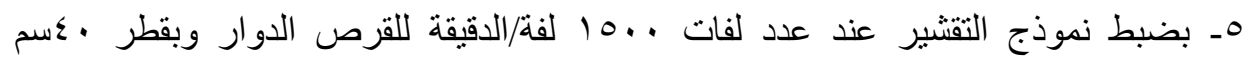

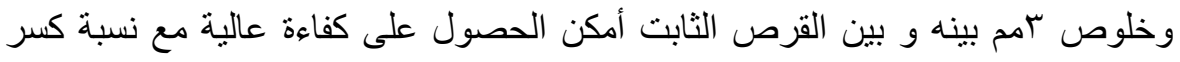

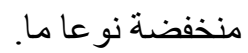

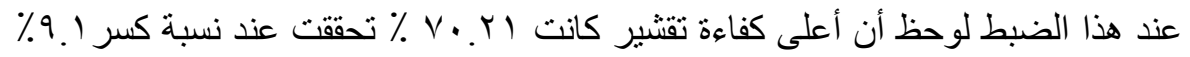

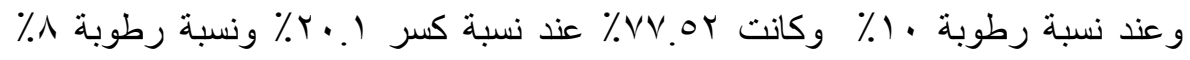

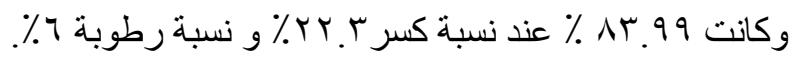
من تقييم النموذج يمكن القول بأنه ملائم لما صمم من أجله كخطوة أولى للوصول إلى الى

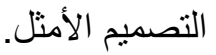

